\title{
Production, absorption, distribution and excretion of vitamin $B_{12}$ in sheep
}

\author{
By R. M. SMITH ANd THE LATE H. R. MARSTON \\ CSIRO Division of Nutritional Biochemistry, \\ Kintore Avenue, Adelaide, South Australia \\ (Received 18 August 1969-Accepted 31 March 1970)
}

\begin{abstract}
I. The efficiency of production and utilization of vitamin $B_{12}$ was studied with sheep given a cobalt-deficient diet with and without supplementary $C o\left(1 \mathrm{mg} / \mathrm{d}\right.$ ). Vitamin $B_{12}$ to lignin ratios in rumen contents were used to estimate minimum rates of production and these were related to faecal and urinary excretion. Tissue distribution and excretion of vitamin $B_{12}$ were studied with $\left[{ }^{58} \mathrm{Co}\right]$ cyanocobalamin and $5^{\prime}$-deoxyadenosyl $\left[{ }^{60} \mathrm{Co}\right]$ cobalamin.

2. Labelled Co was rapidly sequestered by particulate material in the rumen and was largely excreted in the faeces. Most of the vitamin $B_{12}$ in whole rumen contents was contained in micro-organisms, but was released on incubation at $\mathrm{pH}$ 2. Added cyanocobalamin was partly degraded in the rumen.

3. The vitamin $B_{12}$ to lignin ratio in rumen contents began to decline $1-3 \mathrm{~d}$ after cessation of a daily Co drench. Estimated ruminal production of vitamin $B_{12}$ on full feed was not less than $400-700 \mu \mathrm{g} / \mathrm{d}$ with supplementary $\mathrm{Co}$ and $50-110 \mu \mathrm{g} / \mathrm{d}$ from the Co $(0.01-0.05 \mu \mathrm{g} / \mathrm{g}$ dry weight) in the basal diet. Production of vitamin $B_{12}$ appeared to be limited by food intake with or without additional Co.

4. At full feed the efficiency of production of vitamin $B_{12}$ from Co in the basal diet was about $13 \%$ while that from added Co was about $3 \%$. Part of the vitamin $B_{12}$ produced in the rumen was degraded before reaching the faeces and about $5 \%$ was absorbed. The minimum total requirements of sheep for vitamin $B_{12}$ are assessed at about I I $\mu \mathrm{g} / \mathrm{d}$.

5. Injected $5^{\prime}$-deoxyadenosylcobalamin was better retained than injected cyanocobalamin, faecal excretion exceeded urinary excretion with both. Labelled cobalamin was selectively retained by liver (particularly by the mitochondria), kidneys and the walls of parts of the alimentary tract. Vitamin $B_{12}$ was secreted into the duodenum and reabsorbed in the ileum, but little secretion occurred above the duodenum and little absorption below the small intestine.
\end{abstract}

Production of vitamin $B_{12}$ in rumen contents of sheep depends on the presence of cobalt (Hale, Pope, Phillips \& Bohstedt, 1950; Hoekstra, Pope \& Phillips, 1952; Hine \& Dawbarn, 1954; Kercher \& Smith, 1956) and this is reflected in faecal excretion (Hale et al. 1950; Dawbarn, Hine \& Hughes, 1952; Dawbarn \& Hine, 1955). Little is known, however, either of the quantities produced or of the efficiency of absorption.

Kercher \& Smith (1955) estimated that retention of oral cyanocobalamin in sheep was about $3 \%$ that of injected cyanocobalamin, but large doses of injected cyanocobalamin may not be well retained. Thus, with sheep on a Co-deficient diet, I $\mathrm{mg} \mathrm{Co} / \mathrm{d}$ orally led to greater liver storage of vitamin $\mathrm{B}_{12}$ than did $25 \mu \mathrm{g}$ cyanocobalamin/d by injection (Marston, 1970); it led to little urinary excretion but, on the other hand, $30-36 \%$ of injected cyanocobalamin $(5 \circ \mu \mathrm{g} / \mathrm{d})$ was excreted in the urine (Dawbarn \& Hine, I955).

Smith \& Loosli (1957) estimated that sheep given a Co-deficient diet required an additional Io $\mu \mathrm{g}$ injected cyanocobalamin/d, but the amount provided by the diet was unknown. Marston (1970) in long-term experiments has estimated the minimum prophylactic dose of injected cyanocobalamin to be about $6 \mu \mathrm{g} / \mathrm{d}$ for sheep on a diet 
containing $0.03 \mu \mathrm{g} \mathrm{Co} / \mathrm{g}$ (dry). The absolute requirements of sheep for vitamin $\mathrm{B}_{12}$ may be estimated from this dose if both the efficiency of production from the Co in the diet and the efficiency of absorption are known.

The quantities of vitamin $B_{12}$ in rumen contents of sheep given Co-deficient diets are not negligible, and it is not necessarily true that the efficiency of absorption is the same as that when additional Co is supplied or the same as that when crystalline cyanocobalamin is given orally. The work now described was aimed at estimating these rates and efficiencies and in addition at determining the tissue distribution and excretory pattern of injected cobalamins. The total requirements of sheep for vitamin $B_{12}$ are assessed at about I I $\mu \mathrm{g} / \mathrm{d}$ and, although the arguments leading to this estimate are not entirely rigorous, the results permit a reasonable description of the production, absorption and excretion of vitamin $B_{12}$ in the sheep.

\section{EXPERIMENTAL}

Animals and diet. Australian Merino ewes, 2-6 years of age, were fed on a Codeficient diet in cages permitting collection of excreta (Smith \& Marston, 1970). A daily ration was given of $1000 \mathrm{~g}$ wheaten hay-chaff $(0.01-0.05 \mu \mathrm{g} \mathrm{Co} / \mathrm{d}($ dry $)), 5^{\circ} \mathrm{g}$ washed gluten ( $<0.02 \mu \mathrm{g} \mathrm{Co} / \mathrm{g}$ (dry)) and ro g sodium chloride; daily food intakes were recorded and body-weights were measured each week. The ration contained $85-90 \%$ dry matter but unless otherwise stated food intakes are quoted on a moistweight basis.

All animals received weekly drenches supplying $70 \mathrm{mg}$ copper (as sulphate) and $25 \mathrm{ml}$ cod-liver oil. Animals treated with Co were drenched daily at the time of feeding with I $\mathrm{mg} \mathrm{Co}$ (as chloride) in $20 \mathrm{ml}$ water. Animals given vitamin $\mathrm{B}_{12}$ orally received a daily drench of $500 \mu \mathrm{g}$ cyanocobalamin in $20 \mathrm{ml}$ water. Animals treated with vitamin $\mathrm{B}_{12}$ parenterally were injected daily with $50 \mu \mathrm{g}$ cyanocobalamin in $0.5 \mathrm{ml}$ water into the gluteus maximus muscle. Injections of $\left[{ }^{60} \mathrm{Co}\right]$ cyanocobalamin (subcutaneously on the shoulder) or $5^{\prime}$-deoxyadenosyl $\left[{ }^{58} \mathrm{Co}\right]$ cobalamin (into the jugular vein) were given at a rate equivalent to $25 \mu \mathrm{g}$ cyanocobalamin/d in $2 \mathrm{ml}$ isotonic saline.

Samples of rumen contents. These were obtained via fistulas (Jarrett, 1948) with a stainless-steel sampler mounted on a flexible handle. The hollow cylindrical sampler (Io $\mathrm{cm} \times 2.2 \mathrm{~cm}$ diameter) contained a gate $(7.5 \mathrm{~cm} \times \mathrm{r} .8 \mathrm{~cm}$ ) closed by a second hollow cylinder closely fitting inside the first and containing a similar gate. A lever on the handle permitted rotation of the inner cylinder through $180^{\circ}$ to open or close the gate. The closed sampler was inserted into the rumen, the gate was opened for I or $2 \mathrm{~s}$, then closed and the sample ( $15^{-22} \mathrm{~g}$ ) recovered. All samples analysed comprised composites of ten such withdrawals taken from random points in the rumen. Dry-matter measurements of replicate single withdrawals from individual sheep showed the coefficient of variation of such composite samples to be about $3 \%$. Except where otherwise stated, samples of rumen contents were taken $4 \mathrm{~h}$ after feeding.

Chemical estimations. Co in fodder and rumen contents was measured in samples of I 5-25 $\mathrm{g}$ (dry) by the method of Marston \& Dewey (1940). Lignin was measured by the method of Norman \& Jenkins (1934a,b). The dried and ground samples of fodder or 
of $50 \%(\mathrm{v} / \mathrm{v})$ ethanol-insoluble dry matter from rumen contents were refluxed in $5 \%(\mathrm{w} / \mathrm{v}) \mathrm{H}_{2} \mathrm{SO}_{4}$ for $\mathrm{I} h$ to remove protein and hydrolysable polysaccharides, then again dried before leaving for $16 \mathrm{~h}$ at $18^{\circ}$ in $72 \%(\mathrm{w} / \mathrm{w}) \mathrm{H}_{2} \mathrm{SO}_{4}$. The results were corrected for ash content. Nitrogen was estimated by the Kjeldahl procedure of McKenzie \& Wallace (1954). Dry matter in tissues was determined after heating $0.3^{-0.5} \mathrm{~g}$ samples in a drying oven for $18 \mathrm{~h}$ at $105^{\circ}$.

Assay and nomenclature of vitamin $B_{12}$. Vitamin $\mathrm{B}_{12}$ activity was determined microbiologically by four procedures (Ochromonas malhamensis, Lactobacillus leichmanii, Escherichia coli (tube assay) and E. coli (plate assay)) as described by Hine \& Dawbarn (1954). All methods were standardized with cyanocobalamin. Results are expressed as vitamin $\mathrm{B}_{12}$ activity for the particular organism except that vitamin $\mathrm{B}_{12}$ activity for Ochromonas in any material or for L. leichmanii in liver (Hine \& Dawbarn, 1954) are assumed to represent only cobalamins and are referred to as vitamin $B_{12}$.

Measurement of radioactivity. Radioactivity due to ${ }^{58} \mathrm{Co}$ or ${ }^{60} \mathrm{Co}$ was determined with an Ekco scintillation counter type $\mathrm{N}_{55}$ o with an Ekco scaler type $\mathrm{N}_{53} \mathrm{OC}$ (Ekco Electronics Ltd, Southend-on-Sea, Essex). Samples of faeces, alimentary tract contents and those tissues difficult to homogenize were made soluble by wet digestion in boiling nitric acid, sulphuric acid and perchloric acid, made to volume with water and the samples were counted. Soft tissues were homogenized in water for $3 \mathrm{~min}$ in a Servall Omnimixer (Ivan Sorvall Inc., Norwalk, Conn., USA) and samples of the homogenates counted. Urine, whole blood and bile were counted direct. Samples containing ${ }^{58} \mathrm{Co}$ were counted with $15 \%$ efficiency using a probe-type crystal for annular counting. Samples (other than fluids) of $10-20 \mathrm{~g}$ were made to $50 \mathrm{ml}$, and Io $\mathrm{ml}$ counted. Samples containing ${ }^{60} \mathrm{Co}$ were counted with $62 \%$ efficiency using a well-type crystal. Samples (other than fluids) of 2-4 g were made to $20 \mathrm{ml}$, and $5 \mathrm{ml}$ counted. All samples were counted for $10^{3} \mathrm{~s}$. Measured activity of ${ }^{58} \mathrm{Co}$ was corrected for radioactive decay during the experiment, but with ${ }^{60} \mathrm{Co}$ the correction was negligible and was omitted.

Materials. Crystalline cyanocobalamin was obtained from Glaxo-Allenburys (Aust.) Pty Ltd, Melbourne, and was standardized spectrophotometrically at $361 \mathrm{~nm}$ (Barker, Smyth, Weissbach, Munch-Petersen, Toohey, Ladd, Volcani \& Wilson, 1960). ${ }^{60} \mathrm{Co}$ as cobaltous chloride and $\left[{ }^{58} \mathrm{Co}\right]$ cyanocobalamin were obtained from the Radiochemical Centre, Amersham. The latter was diluted with unlabelled cyanocobalamin to a specific activity of $26 \mathrm{nCi} / \mu \mathrm{g}$. $5^{\prime}$-Deoxyadenosyl $\left[{ }^{60} \mathrm{Co}\right]$ cobalamin and also the unlabelled compound were obtained by the courtesy of Dr D. Perlman (E. R. Squibb \& Sons, New Brunswick, NJ, USA). The radioactive coenzyme was chromatographed on Dowex 50 as described by Barker, Smyth, Weissbach, Toohey, Ladd \& Volcani (1960). The final aqueous solution, purged of phenol, was standardized spectrophotometrically at $375 \mathrm{~nm}$ (Barker, Smyth, Weissbach, Toohey et al. 1960) and diluted with the unlabelled compound, similarly standardized to a specific activity of $72 \mathrm{nCi} / \mu \mathrm{g}$. All samples of the coenzyme were carefully protected from light. 
Faecal and urinary excretion of ${ }^{60} \mathrm{Co}$. A 6-year-old ewe (no. I 10) was fed on the Codeficient diet supplemented with Co for 7 months, after which Co treatment was discontinued. The final supplement of $\mathrm{I} \mathrm{mg}$ Co contained $0.2 \mathrm{mCi}{ }^{60} \mathrm{Co}$ and was introduced direct into the rumen through a fistula. Faecal and urinary excretion of ${ }^{60} \mathrm{Co}$ for the following $\mathrm{I} 4 \mathrm{~d}$ are shown in Fig. I. Food intake over this period averaged IOI $6 \mathrm{~g} / \mathrm{d}$.

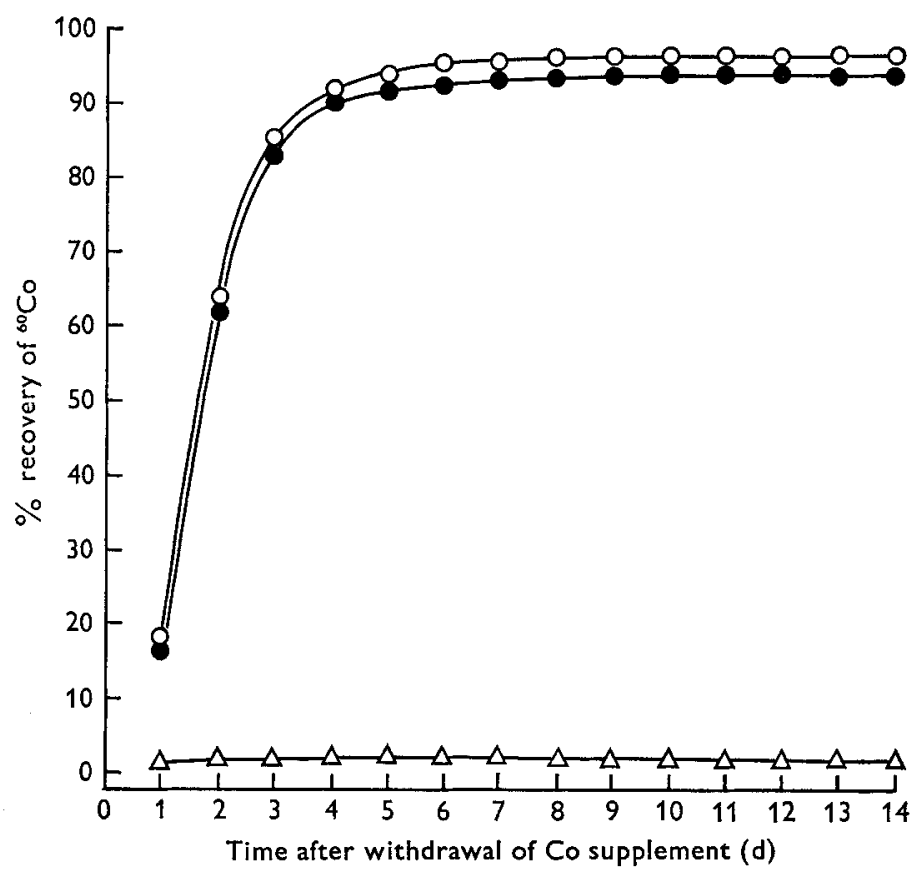

Fig. 1. Excretion of ${ }^{60} \mathrm{Co}$ by sheep after administration of $0.2 \mathrm{mCi}{ }^{60} \mathrm{Co}$ in $\mathrm{I} \mathrm{mg}$ cobalt. $O$, total;, in faeces; $\triangle$, in urine.

Most $(93 \%)$ of the administered ${ }^{60} \mathrm{Co}$ was excreted in the faeces within $5 \mathrm{~d}$. In the I $4 \mathrm{~d}$ period $95 . \mathrm{I} \%$ appeared in the faeces and only $2.5 \%$ in the urine. The results are in general agreement with those of Comar (1948) for cattle, and of Monroe, Sauberlich, Comar \& Hood (1952) for wether lambs.

Distribution of vitamin $B_{12}$ activity in rumen contents. Table I shows the results of two experiments in which vitamin $B_{12}$ distribution was measured. In the first experiment (sample A) an animal on dry summer pasture containing adequate Co ( $0.15 \mu \mathrm{g}$ $\mathrm{Co} / \mathrm{g}$ (dry)) was killed and a portion of whole rumen contents strained under gravity through cheese-cloth. A little over $40 \%$ of the weight of the sample passed freely through, and this and the residual wet fibrous matter were assayed with L. leichmanii for vitamin $B_{12}$ activity, as was the initial sample. The fluid fraction contained only $4 \%$ of the vitamin $B_{12}$ activity, and, even on the assumption that all the residual water in the wet residue contained vitamin $B_{12}$ activity at the same level, less than $10 \%$ 
Vol. 24

Vitamin $B_{12}$ production in sheep

$86 \mathrm{I}$

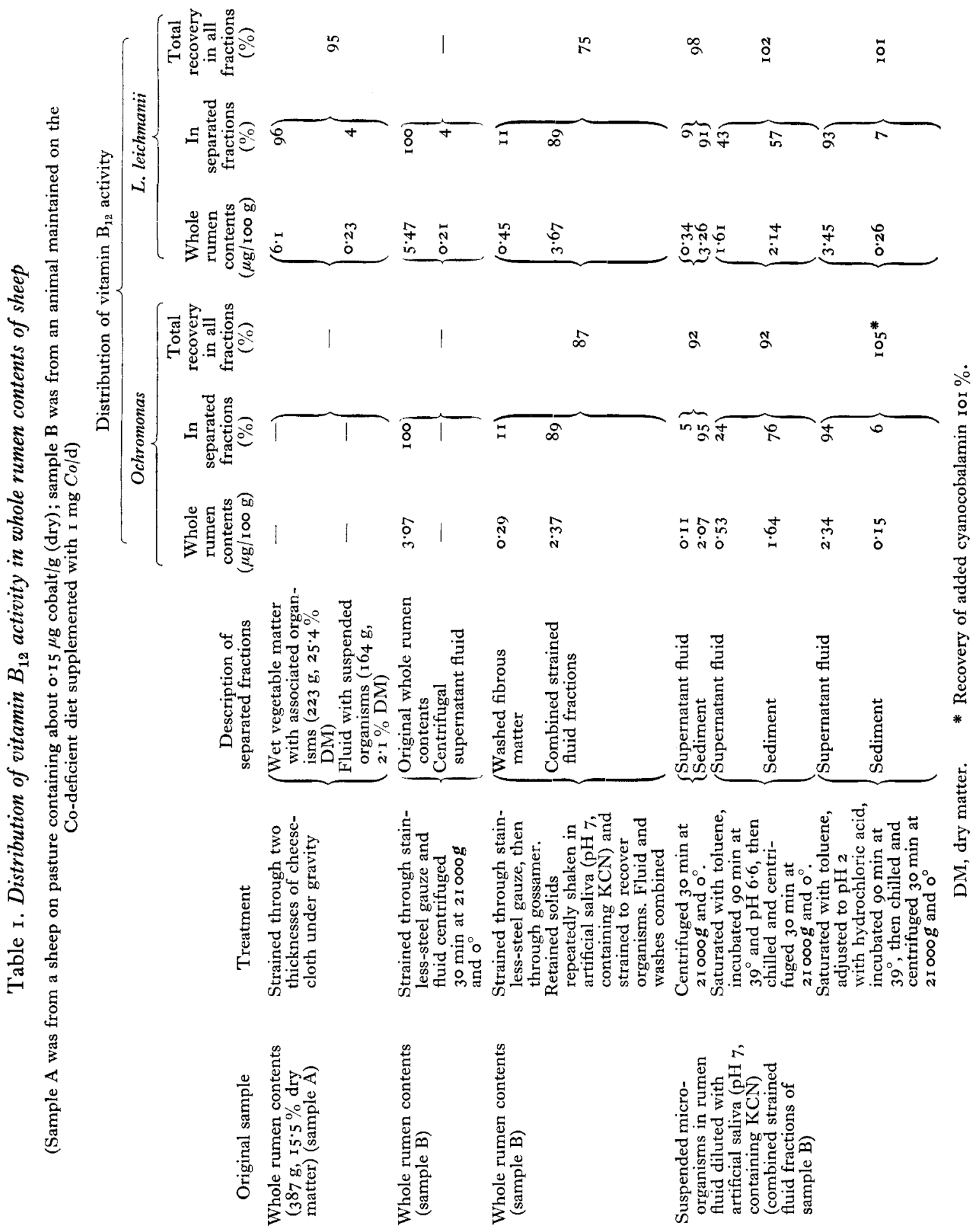


of the activity in whole rumen contents could be regarded as freely detached from fibrous solids.

Distribution of vitamin $\mathrm{B}_{12}$ activity between micro-organisms and fluid in rumen contents (obtained through a fistula) of a sheep eating $105 \circ \mathrm{g} / \mathrm{d}$ of the Co-deficient diet supplemented with $\mathrm{I} \mathrm{mg} \mathrm{Co} / \mathrm{d}$ is shown by the results of the analysis of sample $\mathrm{B}$. The sample was taken $4 \mathrm{~h}$ after feeding and drenching with Co. With the L. leichmanii assay only $4 \%$ of the vitamin $B_{12}$ activity remained in the supernatant fraction after straining and high speed centrifugation. From the Ochromonas assay almost $90 \%$ of the
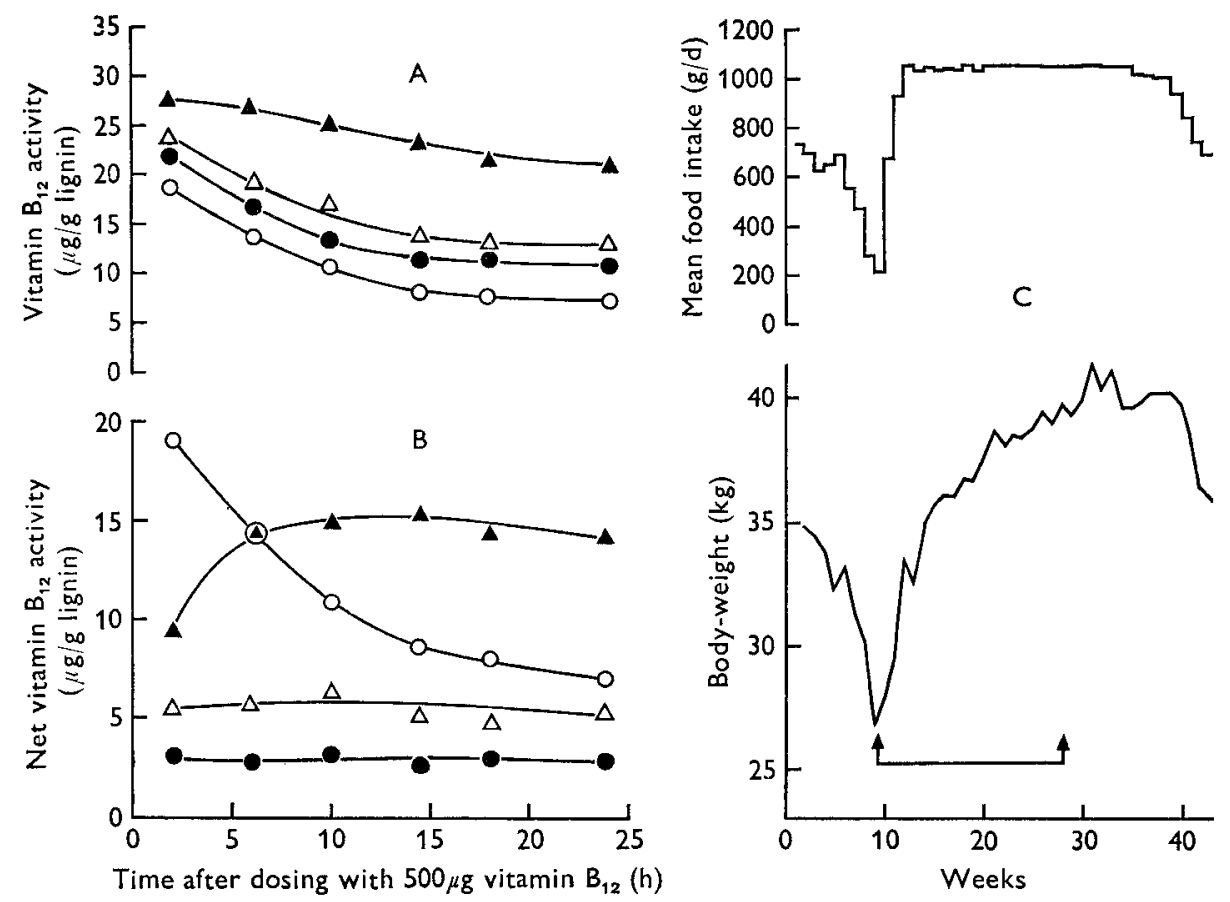

Fig. 2. Degradation of cyanocobalamin introduced into the rumen of sheep. $C$ shows the response in food intake and body-weight of a severely vitamin $B_{12}$-deficient animal to a daily drench of $500 \mu \mathrm{g}$ cyanocobalamin started at the first arrow and discontinued at the second. $A$ and $B$ show the results of microbiological estimations of vitamin $B_{12}$ activity in rumen contents after the first dose. Activity was estimated by Ochromonas malhamensis (O), Lactobacillus leichmanii (৩), Escherichia coli (tube method) $(\triangle)$, and $E$. coli (plate method) $(\boldsymbol{A})$. The total activities are shown in A, and in $\mathrm{B}$ the total activity for Ochromonas, together with the net activities for the other organisms after subtracting the Ochromonas activity.

vitamin $B_{12}$ could be released from fibrous solids by repeated mechanical shaking (four times each for $4 \mathrm{~min}$ ) in McDougall's (1948) artificial saliva (containing $0.005 \%$ $\mathrm{KCN}$ and adjusted to $\mathrm{pH}_{7}$ with $\left.\mathrm{H}_{3} \mathrm{PO}_{4}\right)$. Most $(95 \%)$ of this activity was sedimented on centrifuging and was presumably associated with bacteria. The washed fibrous solids were seen by microscopic examination to contain some residual adherent bacteria.

Incubation for $90 \mathrm{~min}$ at $39^{\circ}(\mathrm{pH} 6.6$ in the presence of toluene) led to release of 
about one-quarter of the vitamin $\mathrm{B}_{12}$ from the bacteria in the fluid phase, but when incubated at $\mathrm{pH} 2(\mathrm{HCl})$ almost all $(94 \%)$ of the vitamin $\mathrm{B}_{12}$ was released.

Degradation of cyanocobalamin introduced into the rumen. An animal (no. 9047) was fed on the Co-deficient diet until it was severely deficient of vitamin $B_{12}$ and was then treated orally with $500 \mu \mathrm{g}$ cyanocobalamin/d. The response is shown in Fig. $2 \mathrm{C}$. Treatment was stopped after 4 months, and 7 weeks later the vitamin $B_{12}$ reserves created by this treatment had been depleted to the point where appetite again failed. (Recovery was immediate on subsequent treatment with $50 \mu \mathrm{g}$ cyanocobalamin/d by injection.)

A

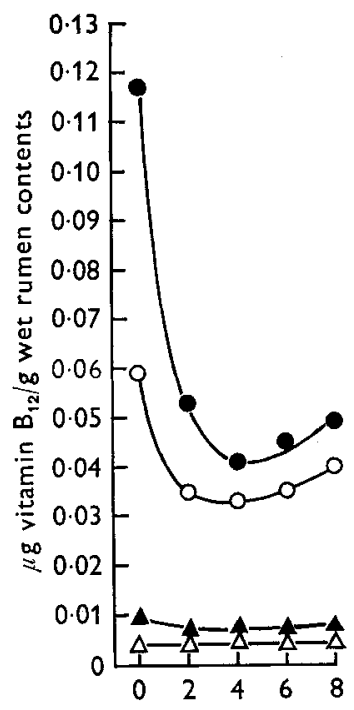

B

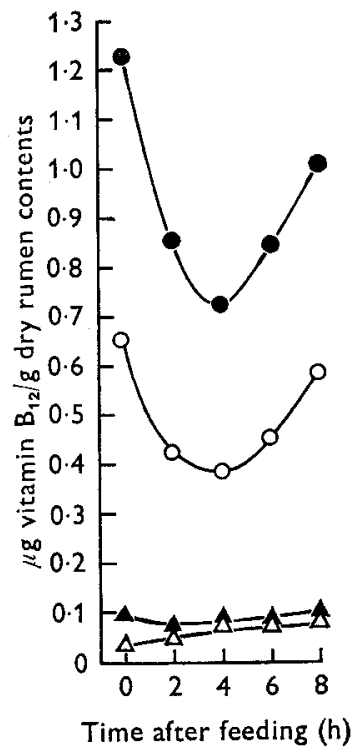

C

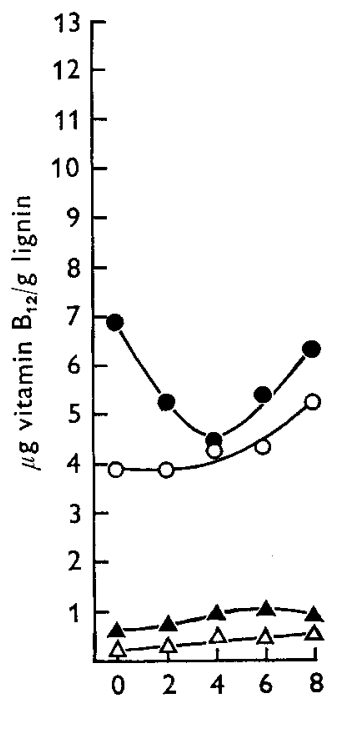

Fig. 3. Ochromonas vitamin $B_{12}$ activity in whole rumen contents of sheep after feeding, expressed as $\mu \mathrm{g}$ cyanocobalamin/g wet matter (A), dry matter (B) or lignin (C), both with and without supplementary cobalt. $O$, animal no. Iıо, +Co;, no. 193 , +Co; $\triangle$, no. IIo, $-\mathrm{Co} ; \boldsymbol{\Delta}$, no. I93, - Co.

Although the daily drench of $500 \mu \mathrm{g}$ cyanocobalamin permitted absorption of sufficient vitamin $B_{12}$ for the animal's needs, little remained for storage. Using the values of Marston (1970) for prophylactic doses of injected cyanocobalamin on this diet, one may calculate that absorption probably lay between $6 \mu \mathrm{g}$ and $\mathrm{I} 2 \mu \mathrm{g} / \mathrm{d}$, or between $\mathrm{I} \%$ and $3 \%$ of the dose.

Degradation of cyanocobalamin in the rumen was detected in samples of rumen contents taken through a fistula at intervals for $24 \mathrm{~h}$ after the first dose. This dose was introduced directly into the rumen and the animal was starved for $24 \mathrm{~h}$. The ratios of vitamin $B_{12}$ activity to lignin for the four assay procedures are shown in Fig. $2 \mathrm{~A}$, and in Fig. $2 \mathrm{~B}$ the same results for vitamin $\mathrm{B}_{12}$ measured with Ochromonas are compared with the activity of factors other than cobalamins active for the other organisms. These were calculated by subtracting the Ochromonas vitamin $\mathrm{B}_{12}$ to lignin ratios from the corresponding ratios obtained by the other methods. 
The rapid decline in the ratio of Ochromonas vitamin $\mathrm{B}_{12}$ to lignin over the first Io $\mathrm{h}$ was accompanied by an increase in net $E$. coli (plate) vitamin $\mathrm{B}_{12}$ to lignin ratio, but there was little change in either net $E$. coli (tube) or net $L$. leichmanii vitamin $\mathrm{B}_{12}$ to lignin ratio.

Production of vitamin $B_{12}$ in the rumen. No completely satisfactory method has been devised for measuring the rate of passage of an unabsorbed substance produced in the rumen of a fed animal. In the present work approximate rates of production of vitamin $\mathrm{B}_{12}$ have been calculated from Ochromonas vitamin $\mathrm{B}_{12}$ to lignin ratios in the rumen $4 \mathrm{~h}$ after feeding, by multiplying by the daily intake of lignin. This method is subject to criticism, and the results, particularly in animals receiving $\mathrm{Co}$, must be regarded as minimum values.

Fig. 3 and Table 2 show the vitamin $B_{12}$ activity in rumen contents at different times during the first $8 \mathrm{~h}$ after feeding, both with and without supplementary Co. Both animals were stabilized for at least $\mathrm{I} 4 \mathrm{~d}$ with or without Co before the measurements were made. Use of the lignin ratio reduced but did not eliminate the effects of rate of consumption of food, and in animals receiving Co the vitamin $B_{12}$ to lignin ratio tended to reach a minimum value $4-6 \mathrm{~h}$ after feeding.

In the experiment shown, the hay-chaff contained $86 \%$ dry matter and $0.03 \mu \mathrm{g} \mathrm{Co} / \mathrm{g}$ (dry) and lignin was $\mathrm{I} \mathrm{I} \cdot \mathrm{I} \%$ of the dry matter. From the lignin intake and the vitamin $\mathrm{B}_{12}$ to lignin ratio $4 \mathrm{~h}$ after feeding, the minimum rates of production of vitamin $\mathrm{B}_{12}$ for animals $I 10$ and 193 respectively were 406 and $423 \mu \mathrm{g} / \mathrm{d}$ when Co was given and 46 and $92 \mu \mathrm{g} / \mathrm{d}$ when Co was withheld. The results for the Co-depleted rumen are also regarded as minimum values because part of the vitamin $B_{12}$ in rumen contents is not associated with lignin-bearing solids (Table 1 ) and Hogan \& Weston (1967) and Weston \& Hogan ( 1967 ) have shown that the rate of turn-over of water through the rumen is faster than that of fibrous solids. The latter error applies to all measurements reported but is probably small. Table 1 shows that vitamin $B_{12}$ is fairly closely associated with lignin-bearing solids in the rumen and suggests that lignin is a reasonably appropriate marker in terms of distribution.

Fig. 4 shows the effects of withdrawal of Co on vitamin $B_{12}$ production in the rumen of two sheep (no. 9029 and no. 9047) previously stabilized for 16 weeks and 2 weeks respectively on I $\mathrm{mg} \mathrm{Co} / \mathrm{d}$. Periodic samples were taken for I $12 \mathrm{~d}$, during which time the mean food intake of no. 9029 was $920 \mathrm{~g} / \mathrm{d}$ and of no. 9047 was $800 \mathrm{~g} / \mathrm{d}$. Calculated from lignin intakes, the minimum rate of vitamin $\mathrm{B}_{12}$ production fell from $600-75^{\circ} \mu \mathrm{g} / \mathrm{d}$ to about $50 \mu \mathrm{g} / \mathrm{d}$ within $5 \mathrm{~d}$ of withdrawal of Co. The latter value was maintained for the remainder of the experiment and reflects synthesis from the Co in the fodder (o.or $\mu \mathrm{g} \mathrm{Co} / \mathrm{g}$ (dry)). In animal 9047 the vitamin $\mathrm{B}_{12}$ to lignin ratio did not fall until the and day after the final drench.

In a further experiment with no. 9029, Co was withdrawn after daily drenching for 4 months. The full ration of $1050 \mathrm{~g} / \mathrm{d}$ was consumed and vitamin $B_{12}$ production fell from a minimum of $480 \mu \mathrm{g} / \mathrm{d}$ to $50 \mu \mathrm{g} / \mathrm{d}$ at $6 \mathrm{~d}$ and $65 \mu \mathrm{g} / \mathrm{d}$ at $14 \mathrm{~d}$ after withdrawal of Co. The diet contained $0.04 \mu \mathrm{g} \mathrm{Co} / \mathrm{g}$ (dry).

Production of other factors with vitamin $B_{12}$ activity in rumen contents. The increases in Ochromonas vitamin $\mathrm{B}_{12}$ to lignin ratios in the rumens of both Co-deficient and 
Vol. 24

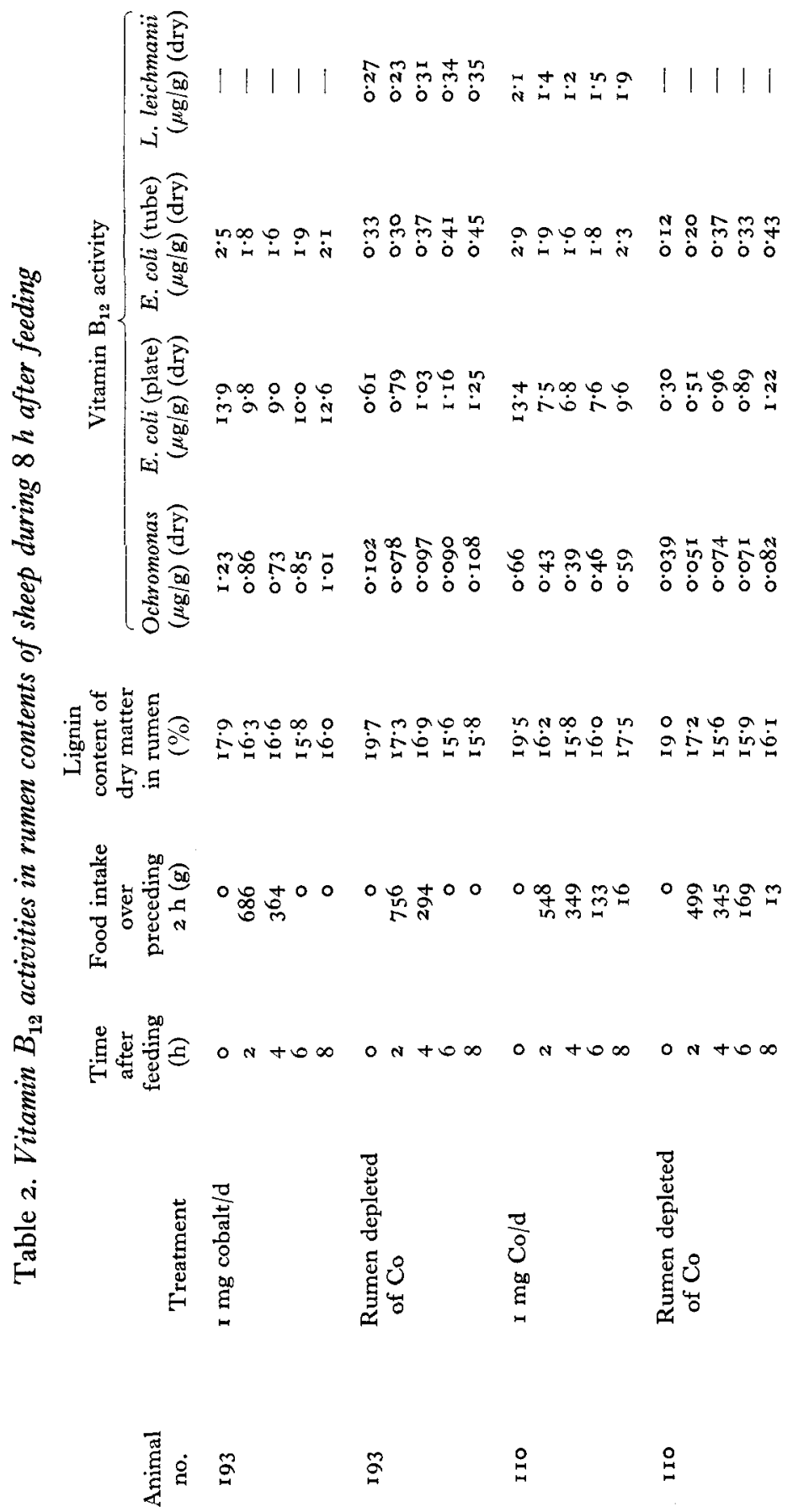


Co-supplemented sheep, shown in Fig. 3, clearly demonstrate synthesis of vitamin $B_{12}$. In both instances simultaneous synthesis of other cobamides may be inferred from Table 2 where the ratios to Ochromonas vitamin $B_{12}$ of the activity for the other test organisms may be calculated and shown to be maintained. In Table 3 are summarized the results of all measurements made of vitamin $\mathrm{B}_{12}$ activity in rumen contents in the present series of studies. In addition to the summarized results of Table 2, the values in

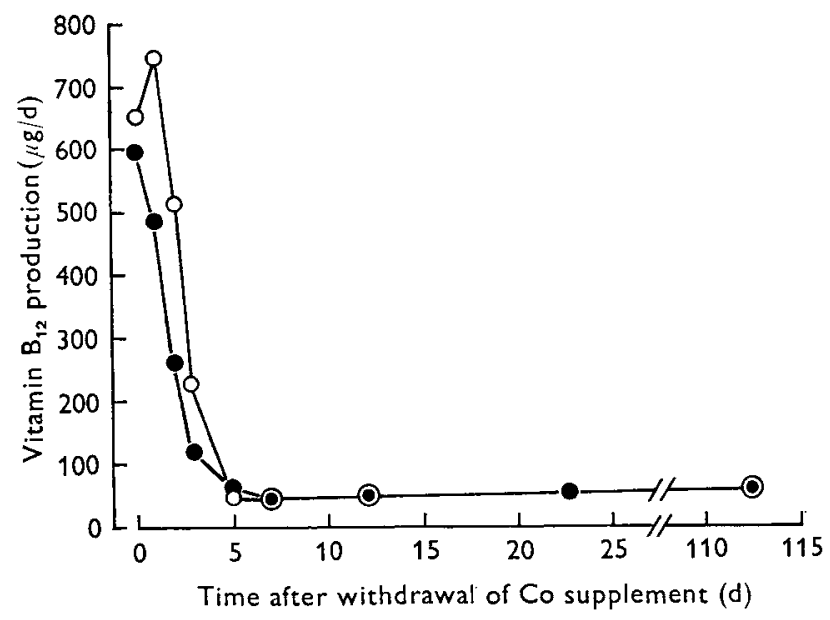

Fig. 4. Minimum rates of production of vitamin $B_{12}$ in the rumen of sheep after withdrawal of a cobalt supplement, estimated from Ochromonas vitamin $\mathrm{B}_{12}$ to lignin ratios in rumen contents $4 \mathrm{~h}$ after feeding. Both animals received $\mathrm{I} \mathrm{mg} \mathrm{Co} / \mathrm{d}$ by mouth before withdrawal on day $\mathrm{O}$.

-, animal 9029; $O$, animal 9047 .

Table 3 include the published results of Hine \& Dawbarn (1954) and Dawbarn, Hine \& Smith (1957). As in Fig. 2, the results for E. coli (plate), E. coli (tube) and L. leichmanii have been expressed as net activities by subtracting the Ochromonas values in order to express the activities of factors other than the cobalamins. In Table 3 the Co-treated animals had received $\mathrm{I} \mathrm{mg} \mathrm{Co} / \mathrm{d}$ for at least $\mathrm{I} 4 \mathrm{~d}$ and the Co-depleted animals had been deprived of supplementary Co for at least $7 \mathrm{~d}$. Both groups subsisted on the Co-deficient diet $(0.01-0.04 \mu \mathrm{g} \mathrm{Co} / \mathrm{g}$ (dry)). Pasture-fed animals consumed a mixed grasslegume diet containing about $0.15 \mu \mathrm{g} \mathrm{Co} / \mathrm{g}$ (dry).

Characteristic differences occurred not only between animals with and without Co ( $\mathrm{I} \mathrm{mg} / \mathrm{d}$ ) on the Co-deficient diet, but also between Co-treated animals and grazing animals on sound pastures. Some of these features were noted by Hine \& Dawbarn (1954).

Rumen contents of Co-deficient animals were characterized by low activities of vitamin $\mathrm{B}_{12}$ measured by all methods. The Co-treated animals showed a high net $E$. coli (plate) activity, and although this was not significantly higher than that in grazing animals, the ratio net $E$. coli (plate) to Ochromonas was significantly higher than that in either Co-deficient or pasture-fed animals. The high activity for Ochromonas in rumen contents of pasture-fed animals, although not significantly greater than that in Cotreated animals, contributed to the significantly lower ratios net $E$. coli (plate) to 
Vol. 24

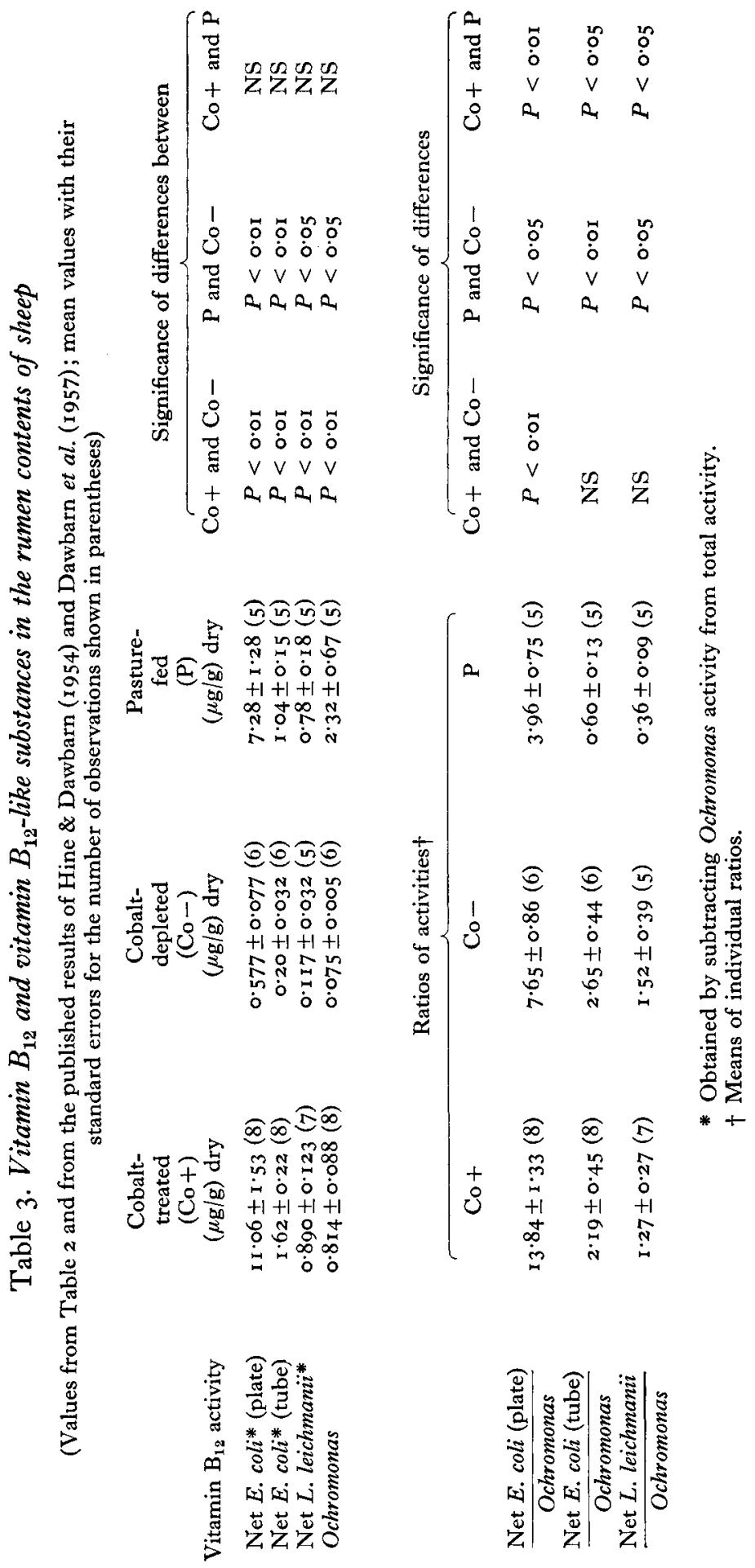


Ochromonas, net $E$. coli (tube) to Ochromonas and net L. leichmanii to Ochromonas in the former, and this feature was characteristic of the grazing animals.

Ruminal production and faecal and urinary excretion of vitamin $B_{12}$ by pair-fed Codeficient and Co-treated ewes at low food intake. Two fistulated ewes (no. 91 $5^{\mathrm{I}}$ and no. 9029) were fed on the Co-deficient diet until food intake fell, when no. 9029 was treated with Co and pair-fed with no. 9151 (Smith \& Marston, 1970). After 8 weeks, when food intake was $33 \circ \mathrm{g} / \mathrm{d}$, samples of rumen contents were taken and faeces and urine collected daily from the following day for $14 \mathrm{~d}$. Further samples of rumen contents were taken on the 15 th day.

Table 4. Estimated minimum rates of ruminal production of vitamin $B_{12}$ in pair-fed vitamin $B_{12}$-deficient and cobalt-treated ewes

\begin{tabular}{|c|c|c|c|c|c|}
\hline Animal no. & Treatment & $\begin{array}{c}\text { Food } \\
\text { intake } \\
(\mathrm{g} / \mathrm{d})(\mathrm{dry})\end{array}$ & $\begin{array}{l}\text { Lignin } \\
\text { intake } \\
(\mathrm{g} / \mathrm{d})\end{array}$ & $\begin{array}{l}\text { Vitamin } \mathrm{B}_{12} \\
\text { in rumen } \\
\text { contents } \\
(\mu \mathrm{g} / \mathrm{g} \text { lignin })\end{array}$ & $\begin{array}{l}\text { Estimated } \\
\text { minimum } \\
\text { rate of } \\
\text { production } \\
\text { of vitamin } \\
\mathrm{B}_{12} \text { in } \\
\text { rumen } \\
(\mu \mathrm{g} / \mathrm{d})\end{array}$ \\
\hline $915 I^{*}$ & $\begin{array}{l}\text { Standard Co- } \\
\text { deficient diet }\end{array}$ & 220 & $23 \cdot I$ & 0.37 & 9 \\
\hline 9029 & $\begin{array}{l}\text { I } \mathrm{mg} \mathrm{Co} / \mathrm{d} \text { and } \\
\text { pair-fed with } 9 \text { I }_{5} \mathrm{I}\end{array}$ & 216 & $22 \cdot 6$ & $5 \cdot 6$ & I 27 \\
\hline
\end{tabular}

The mean value of the vitamin $B_{12}$ to lignin ratio in the rumen contents was used to estimate ruminal vitamin $B_{12}$ production over the $14 \mathrm{~d}$ collection period, and faecal and urinary excretion of vitamin $\mathrm{B}_{12}$ was determined from pooled samples of the excreta (Dawbarn \& Hine, I955). The wheaten hay-chaff used contained I $10 \%$ lignin and $0.04 \mu \mathrm{g} \mathrm{Co} / \mathrm{g}$, both on a dry-weight basis.

Results are shown in Tables 4 and 5. In the deficient animal, daily faecal excretion of vitamin $B_{12}$ was greater than estimated ruminal production, but both quantities were small. In the Co-treated animal, faecal excretion of vitamin $B_{12}$ was somewhat less than the minimum estimated ruminal production. In both instances urinary excretion of vitamin $B_{12}$ was small.

Production of vitamin $B_{12}$ in relation to soluble Co concentration in the rumen. A 5-year-old ewe (no. Iro) was stabilized for several months at full food intake with supplementary Co before Co was withdrawn. For several days before the final Co supplement, samples of rumen contents were taken $4 \mathrm{~h}$ after feeding for estimation of $\mathrm{Co}$, lignin and vitamin $\mathrm{B}_{12}$. The final supplement ( $\mathrm{mg} \mathrm{Co}$ ) contained $\mathrm{I} \cdot 0 \mathrm{mCi}{ }^{60} \mathrm{Co}$ and was introduced direct into the rumen at the time of feeding. Samples of rumen contents were taken $4 \mathrm{~h}$ later and then daily for $8 \mathrm{~d} 4 \mathrm{~h}$ after feeding. Immediately after taking each of these samples a sample of rumen fluid was withdrawn with a syringe and centrifuged for $30 \mathrm{~min}$ at $0^{\circ}$ and $13000 \mathrm{~g}$. The supernatant fluid was essentially free from micro-organisms and was used to estimate ${ }^{60} \mathrm{Co}$ and dry matter. 
The samples of whole rumen contents were analysed for total $\mathrm{Co},{ }^{60} \mathrm{Co}$, dry matter, lignin and Ochromonas vitamin $\mathrm{B}_{12}$.

The measured water content of the two kinds of sample together with the lignin concentrations in whole rumen contents allowed the ${ }^{60} \mathrm{Co}$ values to be expressed as ${ }^{60} \mathrm{Co}$ to lignin ratios for each. On this basis the rate of decline of ${ }^{60} \mathrm{Co}$ with time was

Table 5. Vitamin $B_{12}$ excretion in relation to food intake of pair-fed vitamin $B_{12}$-deficient and cobalt- or vitamin $B_{12}$-treated ewes

\begin{tabular}{|c|c|c|c|c|c|c|}
\hline \multirow[b]{2}{*}{$\begin{array}{l}\text { Expt } \\
\text { no. }\end{array}$} & \multirow[b]{2}{*}{$\begin{array}{l}\text { Animal } \\
\text { no. }\end{array}$} & \multirow[b]{2}{*}{ Treatment } & \multirow{2}{*}{$\begin{array}{l}\text { Period } \\
\text { of pair- } \\
\text { feeding or } \\
\text { recovery } \\
\text { (weeks) }\end{array}$} & \multirow{2}{*}{$\begin{array}{c}\text { Food } \\
\text { intake* } \\
(\mathrm{g}(\mathrm{dry}) / \mathrm{d})\end{array}$} & \multicolumn{2}{|c|}{ Excretion of vitamin $\mathrm{B}_{12}$} \\
\hline & & & & & $\begin{array}{l}\text { Faeces } \\
(\mu \mathrm{g} / \mathrm{d})\end{array}$ & $\begin{array}{l}\text { Urine } \\
(\mu \mathrm{g} / \mathrm{d})\end{array}$ \\
\hline \multirow[t]{2}{*}{ I } & 9134 & Vitamin $\mathrm{B}_{12}$-deficient & - & 180 & 34 & - \\
\hline & 7049 & $\begin{array}{l}\text { I } \mathrm{mg} \mathrm{Co} / \mathrm{d} \text { and pair- } \\
\text { fed with } 9 \text { I } 34\end{array}$ & 27 & 168 & 86 & - \\
\hline \multirow[t]{2}{*}{2} & $915 I$ & Vitamin $B_{12}$-deficient & $\ldots$ & 220 & I 8 & 0.07 \\
\hline & 9029 & $\begin{array}{l}\text { I } \mathrm{mg} \mathrm{Co} / \mathrm{d} \text { and pair- } \\
\text { fed with } 9 \mathrm{I} 5 \mathrm{I}\end{array}$ & 8 & $2 \times 6$ & 92 & 0.76 \\
\hline \multirow[t]{2}{*}{3} & 5009 & Vitamin $B_{12}$-deficient & - & 285 & 21 & 0.09 \\
\hline & 7019 & $\begin{array}{l}50 \mu \mathrm{g} \text { cyanocobalamin } / \mathrm{d} \\
\text { by injection and } \\
\text { pair-fed with } 5009\end{array}$ & I 5 & 275 & 57 & $15 \cdot 2$ \\
\hline \multirow[t]{2}{*}{4} & 9090 & Vitamin $\mathrm{B}_{12}$-deficient & - & 365 & 44 & O. I I \\
\hline & 7009 & $\begin{array}{l}5 \circ \mu \mathrm{g} \text { cyanocobalamin } / \mathrm{d} \\
\text { by injection and } \\
\text { pair-fed with } 9090\end{array}$ & d & 355 & 66 & $17 \cdot 7$ \\
\hline \multirow[t]{2}{*}{5} & 0077 & Co-depleted in rumen + & - & 727 & 127 & 0.26 \\
\hline & 0113 & $\begin{array}{l}\text { I } \mathrm{mg} \mathrm{Co} / \mathrm{d} \text { and } \\
\text { pair-fed with } 0077\end{array}$ & 4 & 727 & 260 & $3 \cdot 6$ \\
\hline \multirow[t]{2}{*}{6} & 0113 & $\begin{array}{l}\text { Co-depleted in } \\
\text { rumen } \ddagger\end{array}$ & - & 723 & 120 & 0.35 \\
\hline & 0077 & $\begin{array}{l}\text { I } \mathrm{mg} \mathrm{Co} / \text { day and } \\
\text { pair-fed with or } 13\end{array}$ & 2 & 723 & 300 & $2 \cdot 7$ \\
\hline \multirow[t]{3}{*}{7} & 5009 & Vitamin $B_{12}$-deficient & - & $\mathbf{I} 96$ & 5 & 0.17 \\
\hline & 5009 & $\begin{array}{l}500 \mu \mathrm{g} \text { cyanoco- } \\
\text { balamin/d by mouth }\end{array}$ & $6-32 \mathrm{~d}$ & $5 \circ 9$ & 120 & 0.24 \\
\hline & & \multicolumn{3}{|c|}{$\begin{array}{l}\text { * From the values of Smith \& Marston (1970). } \\
\dagger \text { From the values of Dawbarn \& Hine (I955). } \\
\ddagger \text { Not deficient of vitamin } B_{12} \text { in their tissues. }\end{array}$} & & \\
\hline
\end{tabular}

found to be accurately exponential in both (except for the first supernatant sample taken $4 \mathrm{~h}$ after ${ }^{60} \mathrm{Co}$ was given). The half-time for decline of ${ }^{60} \mathrm{Co}$ in the supernatant fraction $(20.9 \mathrm{~h})$ was somewhat longer than that in whole rumen contents $(17.5 \mathrm{~h})$ and in consequence, although only $\mathrm{I} \cdot 2 \%$ of the ${ }^{60} \mathrm{Co}$ was present in the supernatant fraction $28 \mathrm{~h}$ after the dose, $8 \mathrm{~d}$ later the amount had risen to $3 \%$. This may have been due to a greater proportion of the supernatant ${ }^{60} \mathrm{Co}$ being present as cobamides as the Co concentration fell. These may not have been so tightly bound by the micro- 
organisms as was ionic Co. In the first sample $(4 \mathrm{~h}), 3 \%$ of the ${ }^{60} \mathrm{Co}$ in whole rumen contents was in the supernatant fraction. Under somewhat similar conditions Tosic \& Mitchell (1948) found about $20 \%$ of administered Co in the supernatant fraction to $h$ after feeding.

The concentration of $\mathrm{Co}$ in the supernatant fraction was calculated from the ${ }^{60} \mathrm{Co}$ content by assuming the specific activity $\left(\mu \mathrm{Ci}{ }^{60} \mathrm{Co} / \mu \mathrm{g} \mathrm{Co}\right)$ to be the same as that measured in corresponding samples of whole rumen contents. These values, expressed as $\mu \mathrm{g} \mathrm{Co} / \mathrm{g}$ water, are shown in Fig. 5, together with the values for vitamin $\mathrm{B}_{12}$ and total $\mathrm{Co}$ in whole rumen contents expressed as ratios to lignin.

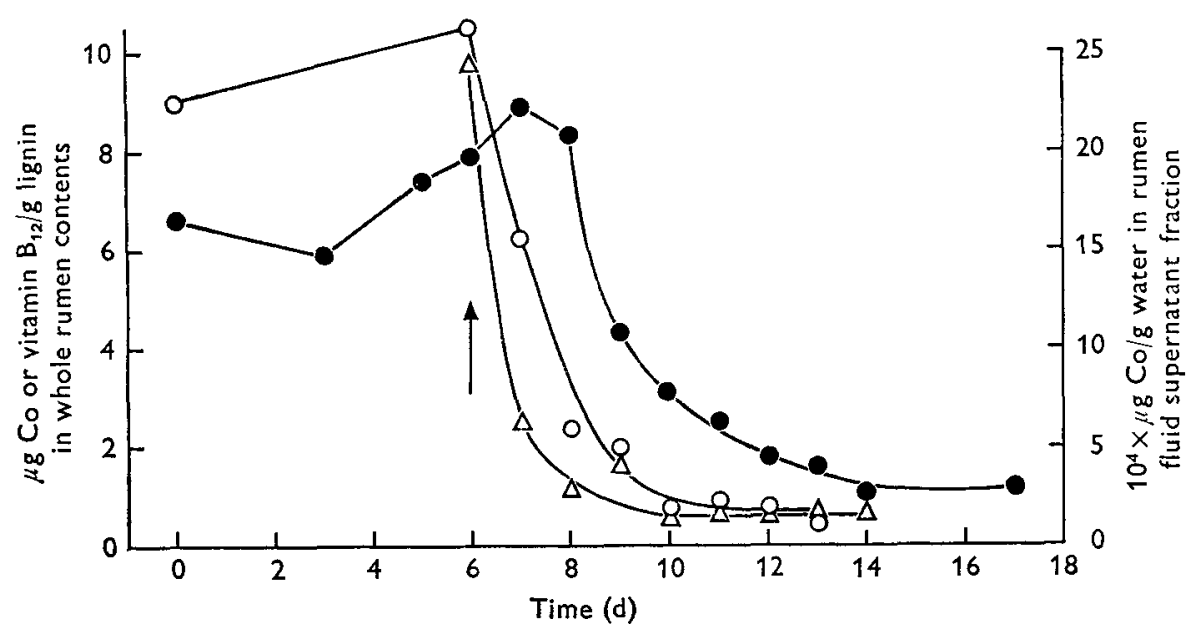

Fig. 5. Concentrations of cobalt and vitamin $B_{12}$ in rumen contents of sheep before and

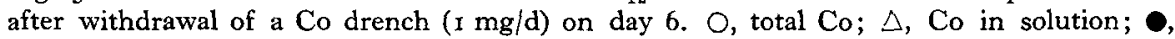
Ochromonas vitamin $\mathrm{B}_{12}$ expressed as cyanocobalamin.

Although both total Co and supernatant Co fell rapidly after the final dose, vitamin $B_{12}$ concentrations did not fall until $2 \mathrm{~d}$ later when supernatant Co was less than $0.5 \mathrm{ng} / \mathrm{ml}$ and total Co less than $20 \mathrm{ng} / \mathrm{g}$ of wet rumen contents. The final concentration of Co in the depleted rumen at $8 \mathrm{~d}$ was steady at less than $0.2 \mathrm{ng} / \mathrm{ml}$ in the supernatant fraction and about $5 \mathrm{ng} / \mathrm{g}$ wet rumen contents (the value for the supernatant fraction was previously reported incorrectly as $20 \mathrm{pg} / \mathrm{ml}$; Marston, Allen \& Smith, I96I). The Co content of the chaff used was $0.53 \mu \mathrm{g} \mathrm{Co} / \mathrm{g}$ lignin and this value was approached in the depleted rumen.

Calculated from daily lignin intakes, the estimated minimum rate of production of vitamin $\mathrm{B}_{12}$ in this experiment fell from $730 \mu \mathrm{g} / \mathrm{d}$ when Co was given to $\mathrm{r}$ 1 $\mu \mathrm{g} / \mathrm{d} 8 \mathrm{~d}$ after it was withdrawn.

Efficiency of conversion of Co into vitamin $B_{12}$ in the rumen. From the Co to lignin and vitamin $B_{12}$ to lignin ratios in whole rumen contents (Fig. 5) the fraction of the total Co present as vitamin $B_{12}$ (cobalamins) may be calculated. These values are shown in Fig. 6 as a function of the Co to lignin ratio. Although the errors in this estimation became considerable at low Co concentrations, the efficiency of conversion of Co into vitamin $B_{12}$ was obviously higher when $C$ o was depleted. 
It was clear from early work (Hale et al. 1950; Hine \& Dawbarn, 1954) that ruminal synthesis of vitamin $\mathrm{B}_{12}$ was more efficient from small quantities of dietary Co than from supplementary $\mathrm{Co}$, and the present results suggest an approximately linear decrease in efficiency from about $15 \%$ in the rumen of animals depleted to about $3 \%$ when I mg Co/d was given.

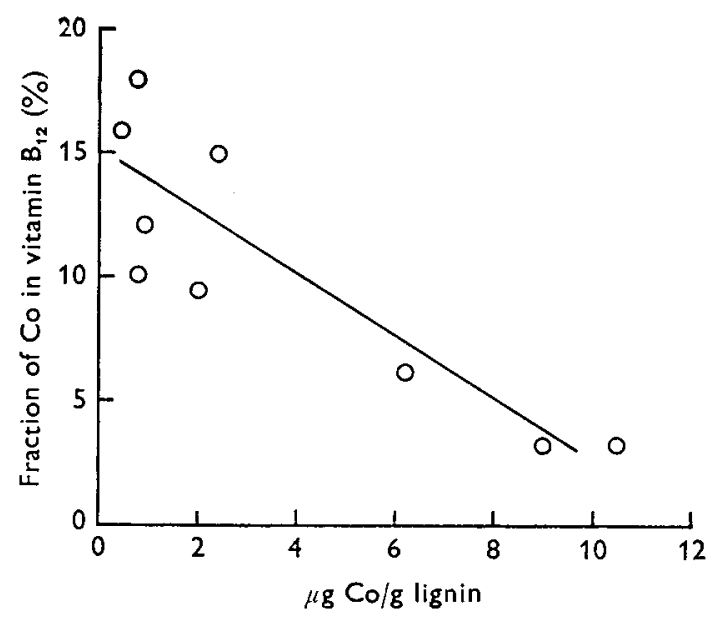

Fig. 6. Relationship between the cobalt concentration in rumen contents of sheep and the percentage present as cobalamins, derived from the values shown in Fig. 5.

Excretion of vitamin $B_{12}$ in faeces and urine. Dawbarn \& Hine (1955) have reported values for mean daily faecal and urinary excretion of vitamin $B_{12}$ by pair-fed Codeficient and Co-treated or vitamin $B_{12}$-treated ewes over $14 \mathrm{~d}$ periods. Nitrogen and combustible energy retention for the same periods were reported (except for the fistulated animals 915I and 9029) by Smith \& Marston (1970). The combined results for food intake and vitamin $B_{12}$ excretion are summarized in Table 5 . In the vitamin $\mathrm{B}_{12}$-deficient animals the severity of the deficiency is indicated by food intake which had fallen from about $940 \mathrm{~g}$ (dry)/d. In Expts 5 and 6, both animals were restricted to the food intakes shown, and in periods without Co these animals were not seriously depleted of vitamin $B_{12}$ in the tissues (Smith \& Marston, 1970).

Also reported by Dawbarn \& Hine (1955) and shown in Table 5 are faecal and urinary excretion of vitamin $B_{12}$ by a severely deficient animal (no. 5009) before and after treatment with $500 \mu \mathrm{g}$ cyanocobalamin/d by mouth. The animal responded to this treatment with increased food intake and body-weight gains, but when the treatment was withdrawn after 9 months it immediately relapsed and had evidently retained barely sufficient vitamin $B_{12}$ for its daily needs. Steady levels of excretion were attained by the 5 th day, and the means of the values 6,13 and $32 \mathrm{~d}$ after treatment was begun are given in Table 5. If the requirement of injected cyanocobalamin is about $6 \mu \mathrm{g} / \mathrm{d}$ (Marston, 1970), only about I \% of the dose can have been absorbed even though a little more than $20 \%$ appeared in the faeces.

As noted by Dawbarn \& Hine (I955), urinary excretion in animals fed on this diet 
with or without supplementary Co was seldom more than I \% of faecal excretion, but when cyanocobalamin was injected $(50 \mu \mathrm{g} / \mathrm{d}) 30-36 \%$ was excreted in the urine and most of the remainder in the faeces.

Table 6. Distribution of ${ }^{58} \mathrm{Co}$ in tissues and alimentary tract contents after subcutaneous injection of $\left.500 \mu \mathrm{g}{ }^{58} \mathrm{Co}\right]$ cyanocobalamin $(\mathrm{1} 3 \mu \mathrm{Ci})$ over 20 d into a vitamin $B_{12^{-}}$deficient sheep

\begin{tabular}{|c|c|c|c|c|c|c|c|}
\hline \multirow{2}{*}{$\begin{array}{l}\text { Organ, tissue or } \\
\text { section of } \\
\text { alimentary tract }\end{array}$} & \multicolumn{3}{|c|}{ Tissues } & \multicolumn{4}{|c|}{ Contents of alimentary tract } \\
\hline & $\begin{array}{c}\text { Wet } \\
\text { weight } \\
\text { (g) }\end{array}$ & $\begin{array}{c}\text { Specific } \\
\text { activity } \\
\text { (nCi/g) } \\
\text { (wet) }\end{array}$ & $\begin{array}{l}\text { Percent- } \\
\text { age of } \\
\text { total } \\
\text { admini- } \\
\text { stered } \\
\text { dose }\end{array}$ & $\begin{array}{c}\text { Wet } \\
\text { weight } \\
\text { (g) }\end{array}$ & $\begin{array}{c}\text { Dry } \\
\text { matter } \\
(\%)\end{array}$ & $\begin{array}{c}\text { Specific } \\
\text { activity } \\
\text { (nCi/g) } \\
\text { (dry) }\end{array}$ & $\begin{array}{l}\text { Percent- } \\
\text { age of } \\
\text { total } \\
\text { admini- } \\
\text { stered } \\
\text { dose }\end{array}$ \\
\hline Liver & 401 & $5 \cdot 35$ & $16 \cdot 5$ & - & - & - & - \\
\hline Kidneys & $8 I$ & $8 \cdot 42$ & $5 \cdot 3$ & 一 & 一 & - & - \\
\hline Spleen & 55 & I. 45 & 0.6 & - & - & - & 一 \\
\hline Lungs & 385 & $\mathrm{I} \cdot 03$ & $3 \cdot \mathrm{I}$ & - & - & - & $\cdots$ \\
\hline Brain & 95 & 0.40 & 0.3 & - & $\rightarrow$ & - & - \\
\hline Heart & I 58 & 0.35 & 0.4 & - & - & - & 一 \\
\hline Skeletal muscle & - & 0.13 & - & - & - & - & - \\
\hline Bone marrow & - & $<0.05$ & - & - & $\cdots$ & - & 一 \\
\hline Blood & - & 0.08 & - & - & - & - & $一$ \\
\hline Gall biadder & 2 & 0.72 & - & - & - & - & - \\
\hline Gall bladder contents & $2 \cdot 4$ & 0.59 & - & $\longrightarrow$ & - & - & - \\
\hline Oesophagus & 37 & 0.27 & $<O . I$ & - & 一 & - & - \\
\hline Rumen & 472 & $2 \cdot 90$ & 10.5 & $3 \times 50$ & 16.4 & 0.12 & 0.5 \\
\hline Reticulum & $1 \times 9$ & $2 \cdot 05$ & $I \cdot 9$ & 330 & $12 \cdot 6$ & $<0.05$ & $<0.1$ \\
\hline Omasum & 133 & 3.06 & $3 \cdot 2$ & $16 I$ & $17 \cdot 2$ & 0.33 & $<0 . I$ \\
\hline Abomasum & I 78 & $0.8 I$ & $1 \cdot 2$ & 286 & 10.4 & 0.54 & $0 . I$ \\
\hline Duodenum & 9 & $I \cdot I 8$ & $<0.1$ & 12 & $6 \cdot 2$ & 3.06 & $<0.1$ \\
\hline Ileum I & 40 & $2 \cdot 24)$ & & 69 & 10.5 & $(\cdot 8 I)$ & \\
\hline 2 & 43 & $I \cdot 2 x$ & & 98 & 10.3 & $2 \cdot 19$ & \\
\hline 3 & 20 & $\mathrm{r} \cdot 42$ & & 73 & 10.9 & $I \cdot 47$ & \\
\hline 4 & 25 & I. 49 & 2.8 & 75 & $7 \cdot 6$ & $2 \cdot 19$ & 0.8 \\
\hline 5 & 75 & $x \cdot 71$ & $3 \cdot 8$ & 140 & $8 \cdot 0$ & $2 \cdot 22$ & \\
\hline 6 & 33 & $\mathrm{I} \cdot \mathrm{IO}$ & & 93 & $7 \cdot 5$ & $x \cdot 42$ & \\
\hline 7 & $4 I$ & $I \cdot 53$ & & 109 & $6 \cdot 6$ & 0.44 & \\
\hline 8 & 44 & $I \cdot 51)$ & & 92 & $7 \cdot 0$ & $0.41)$ & \\
\hline Caecum & I 44 & 0.82 & 0.9 & 580 & I I 4 & 0.64 & 0.4 \\
\hline Colon I & $5^{8}$ & 0.71 & & 75 & 14.5 & 0.55 & \\
\hline 2 & 53 & 0.63 & & $5^{8}$ & $18 \cdot 2$ & 0.68 & \\
\hline 3 & 58 & 0.86 & $x \cdot 3$ & 50 & 23.5 & $0.86\}$ & 0.3 \\
\hline 4 & 80 & $0.5^{8}$ & & 44 & $21 \cdot 7$ & 0.68 & \\
\hline Rectum & 89 & 0.40 & 0.3 & 34 & $27 \cdot 4$ & $0.5 \mathrm{I}$ & $<0.1$ \\
\hline
\end{tabular}

Excretion and tissue distribution of $\left[{ }^{58} \mathrm{Co}\right]$ cyanocobalamin injected into a vitamin $B_{12^{-}}$ deficient sheep. A vitamin $\mathrm{B}_{12}$-deficient ewe (no. 830, body-weight $24 \mathrm{~kg}$, food intake $\left.44^{\circ} \mathrm{g} / \mathrm{d}\right)$ was injected subcutaneously with $25 \mu \mathrm{g}(0.65 \mu \mathrm{Ci})\left[{ }^{58} \mathrm{Co}\right]$ cyanocobalamin/d for $20 \mathrm{~d}$ and was killed on the $2 \mathrm{Ist}$ day. Food intake increased to $880 \mathrm{~g} / \mathrm{d}$ and bodyweight to $27 \mathrm{~kg}$ during treatment.

Daily measurements of faecal and urinary ${ }^{58} \mathrm{Co}$ showed that during the 2I $\mathrm{d}$ I $9.9 \%$ of the labelled vitamin $\mathrm{B}_{12}$ was excreted in the faeces and $13.3 \%$ in the urine. In a previous similar experiment lasting for $7 \mathrm{~d}$ (animal no. 377), $7 \cdot 2 \%$ of the injected 
label appeared in the faeces and $8.4 \%$ in the urine. Net retention of injected vitamin $B_{12}$ by the tissues of deficient animals was therefore high, but the distribution of excreted vitamin $B_{12}$ between faeces and urine was similar to that of repleted animals (Table 5).

Table 7. Distribution of ${ }^{60} \mathrm{Co}$ in tissues and alimentary tract contents after intravenous injection of $3^{\circ} 4 \mu \mathrm{g} 5^{\prime}$ deoxyadenosyl $\left[{ }^{60} \mathrm{Co}\right]$ cobalamin $(2 \mathrm{I} \cdot 9 \mu \mathrm{Ci})$ over ro dinto a vitamin $B_{12}$-deficient sheep

\begin{tabular}{|c|c|c|c|c|}
\hline \multirow[b]{2}{*}{$\begin{array}{l}\text { Organ, tissue or } \\
\text { section of } \\
\text { alimentary tract }\end{array}$} & \multicolumn{2}{|c|}{ Tissues } & \multicolumn{2}{|c|}{ Contents of alimentary tract } \\
\hline & $\begin{array}{c}\text { Specific } \\
\text { activity } \\
\text { (nCi/g) (wet) }\end{array}$ & $\begin{array}{c}\text { Dry } \\
\text { matter } \\
(\%)\end{array}$ & $\begin{array}{c}\text { Dry } \\
\text { matter } \\
(\%)\end{array}$ & $\begin{array}{c}\text { Specific } \\
\text { activity } \\
(\mathrm{nCi} / \mathrm{g})(\mathrm{dry})\end{array}$ \\
\hline Liver & I9.6 & $24 \cdot 0$ & 一 & - \\
\hline Kidneys & $17 \cdot 0$ & $17 \cdot 6$ & - & - \\
\hline Spleen & $5 \cdot 0$ & $23 \cdot 6$ & - & 一 \\
\hline Pancreas & $3 \cdot 6$ & $2 \mathrm{I} \cdot \mathrm{O}$ & - & - \\
\hline Submaxillary gland & 3.9 & $2 I \cdot 0$ & 一 & - \\
\hline Adrenals & $3 \cdot 4$ & $19 \cdot 1$ & - & - \\
\hline Ovary & $4 \cdot 2$ & $16 \cdot 0$ &.- & - \\
\hline Thyroid & $5 \cdot 2$ & $2 \mathrm{I} \cdot 8$ & - & - \\
\hline Lung & $2 \cdot 0$ & $13 \cdot 9$ & $\rightarrow$ & 一 \\
\hline Heart & $I \cdot 0$ & $1 \mathrm{I} \cdot 6$ & - & $\longrightarrow$ \\
\hline Skeletal muscle & 0.2 & $29 \cdot 0$ & - & - \\
\hline Bile & 0.03 & - & - & -- \\
\hline Rumen & $4 \cdot 3$ & $17 \cdot 5$ & I $2 \cdot 6$ & 0.3 \\
\hline Reticulum & $4 \cdot x$ & 14.9 & - & - \\
\hline Abomasum & $2 \cdot 2$ & $2 \mathrm{I} \cdot 7$ & $9 \cdot 9$ & $\mathrm{I} \cdot 2$ \\
\hline Duodenum & $3 \cdot 7$ & $18 \cdot I$ & $6 \cdot 5$ & $9 \cdot 3$ \\
\hline Ileum I & $3 \cdot 3$ & 14.9 & $8 \cdot 8$ & 15.7 \\
\hline 2 & 3.5 & $16 \cdot 6$ & II 6 & $12 \cdot 6$ \\
\hline 3 & $3 \cdot 8$ & $16 \cdot 5$ & $6 \cdot I$ & 10.4 \\
\hline 4 & $2 \cdot 9$ & $13 \cdot I$ & $8 \cdot \mathbf{I}$ & $5 \cdot I$ \\
\hline 5 & 0.8 & $8 \cdot 8$ & $8 \cdot 6$ & $3 \cdot 3$ \\
\hline 6 & 0.3 & 9.0 & $8 \cdot 7$ & 3.5 \\
\hline 7 & $3 \cdot 5$ & $15 \cdot 3$ & $8 \cdot 4$ & $2 \cdot 5$ \\
\hline 8 & $2 \cdot 8$ & 13.0 & $8 \cdot 5$ & $I \cdot 3$ \\
\hline Caecum & $2 \cdot 3$ & I $8 \cdot 9$ & I $4 \cdot I$ & I. 7 \\
\hline Colon I & 3.0 & $15 \cdot 2$ & $17 \cdot 7$ & $I \cdot O$ \\
\hline 2 & $2 \cdot 7$ & $21 \cdot 0$ & $22 \cdot 2$ & I'O \\
\hline 3 & $2 \cdot 1$ & $20 \cdot 3$ & $22 \cdot 6$ & 0.8 \\
\hline Rectum & $\mathrm{I} \cdot 8$ & $32 \cdot 2$ & $23 \cdot 8$ & $I \cdot I$ \\
\hline
\end{tabular}

The distribution of labelled vitamin $\mathrm{B}_{12}$ in tissues and alimentary tract contents of animal 830 was determined at slaughter. Immediately after death the small and large intestines were ligated in sections and the contents of each section gently extruded and collected. The contents of the remainder of the alimentary tract were separated and collected without ligation. After extrusion of contents, the sections of gut were rinsed out with isotonic saline and retained for analysis. Table 6 shows the results for alimentary tract contents on a dry-weight basis and for tissues on a wet-weight basis.

Excretion and tissue distribution of $5^{\prime}$-deoxyadenosyl $\left[{ }^{60} \mathrm{Co}\right]$ cobalamin in a vitamin $B_{12^{-}}$ deficient sheep. A vitamin $\mathrm{B}_{12}$-deficient ewe (no. 519 , body-weight $27 \mathrm{~kg}$, food intake $260 \mathrm{~g} / \mathrm{d})$ was injected intravenously with $30^{\circ} 4 \mu \mathrm{g}(2 \cdot 19 \mu \mathrm{Ci}) 5^{\prime}$-deoxyadenosyl $\left[{ }^{60} \mathrm{Co}\right] \mathrm{co}-$ balamin/d for ro $\mathrm{d}$ and killed on the $\mathrm{I}$ th day. Food intake increased to $640 \mathrm{~g}$ on the 
Ioth day of treatment and body-weight to $30 \mathrm{~kg}$. Samples of tissues and alimentary tract contents were collected at slaughter as before and in addition a sample of liver was chilled and homogenized in $0.25 \mathrm{M}$-sucrose for centrifugal separation of intracellular components (Smith, Osborne-White \& Russell, I965).

Table 8. Subcellular distribution of ${ }^{60} \mathrm{Co}$ in liver after intravenous injection of $5^{\prime}$-deoxyadenosyl $\left[{ }^{60} \mathrm{Co}\right]$ cobalamin injected into a sheep

(A sample of the liver referred to in Table 7)

\begin{tabular}{|c|c|c|c|c|}
\hline Starting material & Derived fraction & $\begin{array}{l}{ }^{\mathrm{B}} \mathrm{Co} \\
\text { recovered } \\
\text { from } \\
\mathrm{I} 4 \cdot 7 \mathrm{~g} \\
\text { liver } \\
\text { (nCi) }\end{array}$ & $\begin{array}{l}\text { Nitrogen } \\
\text { recovered } \\
\text { from } \\
\text { 14.7 } \mathrm{g} \\
\text { liver } \\
(\mathrm{mg})\end{array}$ & $\begin{array}{c}\text { Activity } \\
(\mathrm{nCi} / \mathrm{mg} \mathrm{N})\end{array}$ \\
\hline Whole liver & Total & 270 & 393 & 0.69 \\
\hline $\begin{array}{l}\text { Homogenate in } \\
0.25 \mathrm{M} \text {-sucrose }\end{array}$ & $\begin{array}{l}\text { Nuclear-free homogenate } \\
(600 \mathrm{~g} \text { supernatant) } \\
\text { Nuclear fraction } \\
\text { (600 } \mathrm{g} \text { sediment) }\end{array}$ & $\begin{array}{l}171 \\
95 \cdot 2\end{array}$ & $\begin{array}{r}233 \\
176\end{array}$ & $\begin{array}{l}0.73 \\
0.54\end{array}$ \\
\hline $\begin{array}{c}\text { Nuclear-free } \\
\text { homogenate }\end{array}$ & $\begin{array}{l}\text { Washed mitochondria } \\
\text { Mitochondrial wash fluid } \\
\text { Microsomes } \\
\text { Soluble fraction }\end{array}$ & $\begin{array}{r}89 \cdot 2 \\
2 \cdot 4 \\
4 \cdot 4 \\
68 \cdot 5\end{array}$ & $\begin{array}{r}58.4 \\
19.7 \\
40.9 \\
125.8\end{array}$ & $\begin{array}{l}1.53 \\
0.12 \\
0.11 \\
0.55\end{array}$ \\
\hline $\begin{array}{l}\text { Washed mito- } \\
\text { chondria }\end{array}$ & $\begin{array}{l}\text { Centrifugal supernatant from } \\
\text { mechanically disrupted } \\
\text { mitochondria* }\end{array}$ & $59 \cdot 3$ & $21 \cdot 9$ & $2 \cdot 71$ \\
\hline
\end{tabular}

Table 7 shows the distribution of labelled cobalamins in tissues and tract contents, and Table 8 shows the distribution in the liver homogenate. At the end of the ro $d$ period $5.7 \%$ of the injected labelled material had been excreted in the faeces and $2.5 \%$ in the urine. The liver retained $25.6 \%$ of the injected coenzyme, and a large proportion of this $(52 \%$ of the activity of the nuclear-free homogenate) was firmly retained within the mitochondria. There was no evidence of accumulation by microsomes. The nuclear fraction had a lower activity relative to nitrogen than did the whole homogenate and although this fraction was heavily contaminated with unbroken cells and cell debris, it is concluded that ${ }^{60} \mathrm{Co}$ did not accumulate in the nuclei.

\section{DISCUSSION}

With animals receiving I mg Co/d on full or near-full feed, the six estimates of minimum production rates of vitamin $\mathrm{B}_{12}$ ranged from $4 \mathrm{I} 0$ to $730 \mu \mathrm{g} / \mathrm{d}$, the lower values corresponding in general to high rates of feeding during the $4 \mathrm{~h}$ before sampling. These values represent a range of minimum efficiencies of conversion of Co into vitamin $\mathrm{B}_{12}$ from $\mathrm{I} \cdot 7 \%$ to $3 . \mathrm{I} \%$ based on total daily Co intakes. From Fig. 6 the fraction of ruminal Co present as vitamin $\mathrm{B}_{12}$ under these conditions was about $3 \%$. The agreement between this value and the highest of the estimated minimum efficiencies provides the basis for an assessment of ruminal vitamin $B_{12}$ production at about 
$700 \mu \mathrm{g} / \mathrm{d}$. In the single ewe studied at low food intake (Table 4), the same Co supplement produced a similar vitamin $\mathrm{B}_{12}$ to lignin ratio in rumen contents, suggesting that vitamin $B_{12}$ production was limited by food intake rather than by $\mathrm{Co}$ at this level. The rough correlation between food intake and daily faecal excretion of vitamin $B_{12}$ in animals receiving Co (Table 5) supports this contention.

In the Co-depleted rumen the minimum estimates of vitamin $\mathrm{B}_{12}$ production ranged from 46 to $110 \mu \mathrm{g} / \mathrm{d}$ on full feed, the variation depending in part on the Co content of the diet. Based on dietary Co intakes, the corresponding efficiencies ranged from $5 \%$ to $18 \%$ (mean I2 \%), and from Fig. 6 the fraction of Co present as vitamin $\mathrm{B}_{12}$ in rumen contents was about $15 \%$. From these values the efficiency of conversion of dietary Co into vitamin $B_{12}$ with the feed used is assessed at $13 \pm 5 \%$, and this did not appear to be altered at low food intake.

The efficiency of production of vitamin $B_{12}$ from Co was undoubtedly affected by the nature of the diet. Measured by microbiological assay, rumen contents from pasturefed animals contained a significantly greater proportion of their total vitamin $B_{12}$ activity as cobalamins than did animals on the experimental diet either with or without Co. This is consistent with the electrophoretic results of Dawbarn et al. (1957), but the high $E$. coli (plate) activity in animals on the experimental diet supplemented with Co is unexplained. Of the cobamides and cobinamides known to be present in rumen contents (Porter, 1953, 1957) only Factor B (cobinamide) leads to this kind of response (Smith, 1965); Dawbarn et al. (1957) found little Factor B in rumen contents of Co-treated animals.

The estimated efficiency of absorption of cyanocobalamin given orally $(1-3 \%)$ is consistent with previous estimates (Kercher \& Smith, 1955; Marston, 1970) but cyanocobalamin in the rumen was fairly rapidly destroyed and little more than $20 \%$ of the daily dose appeared in the faeces. From the $E$. coli (plate) response, Factor B appeared to be a major product of degradation of cyanocobalamin in the rumen, and the virtual absence of Factor B from rumen contents of pasture-fed or Co-treated animals (Dawbarn et al. 1957) suggests that bacterially bound vitamin $\mathrm{B}_{12}$ in the rumen may not be so readily degraded. This is particularly apparent in pasture-fed animals where high Ochromonas vitamin $\mathrm{B}_{12}$ levels were accompanied by relatively low net activities for the other test organisms.

Destruction of vitamin $B_{12}$ produced from $C o$ in the rumen cannot be reliably assessed from faecal excretion because of possible synthesis in the lower gut (Kercher \& Smith, 1956), but daily faecal vitamin $B_{12}$ in Co-treated animals was about half the estimated ruminal production. In the absence of supplementary $\mathrm{Co}$, faecal excretion of vitamin $B_{12}$ may have been affected in addition by a net loss of vitamin $B_{12}$ from the tissues. In severely deficient animals at low food intake, mean daily faecal vitamin $B_{12}$ represented $12 \%$ of dietary Co but in animals not depleted of tissue vitamin $B_{12}$ this fraction was $21 \%$ and probably exceeded ruminal production. Destruction of ruminal vitamin $\mathrm{B}_{12}$ undoubtedly occurred during passage through the alimentary tract, but it may not have been as extensive as that of cyanocobalamin given by drench.

Absorptive efficiencies of vitamin $\mathrm{B}_{12}$ may be calculated for both Co-treated and Co-deficient animals. By extrapolation from liver storage of vitamin $B_{12}$ in sheep on 
graded doses of injected cyanocobalamin, Marston ( 1970 ) estimated that about $34 \mu \mathrm{g}$ vitamin $\mathrm{B}_{12} / \mathrm{d}$ were absorbed in animals receiving $\mathrm{I} \mathrm{mg}$ (or Io $\mathrm{mg}$ ) $\mathrm{Co} / \mathrm{d}$. (This is a maximum value that neglects excess urinary excretion of injected cyanocobalamin.) From the present estimate of ruminal production $(700 \mu \mathrm{g} / \mathrm{d})$, this represents an absorptive efficiency of about $5 \%$. For animals on a diet containing $0.03 \mu \mathrm{g} \mathrm{Co} / \mathrm{g}$ (dry), the minimum prophylactic dose of injected cyanocobalamin was about $6 \mu \mathrm{g} / \mathrm{d}$, and of oral Co was about $40 \mu \mathrm{g} / \mathrm{d}$. On the assumption that $13 \%$ of dietary Co was converted into vitamin $\mathrm{B}_{12}$, the efficiency of absorption was again about $5 \%$.

Using these estimates, an assessment may now be made of the total requirements of sheep for vitamin $B_{12}$ either from the minimum requirement for $\mathrm{Co}(7 \circ \mu \mathrm{g} / \mathrm{d}$, Marston 1970) or from the minimum requirement for injected cyanocobalamin on a diet containing $0.03 \mu \mathrm{g} \mathrm{Co} / \mathrm{g}$ (dry). The total requirement is assessed at about I I $\mu \mathrm{g} / \mathrm{d}$.

'The site of absorption of vitamin $B_{12}$ appears to be the small intestine, as in other animals. Substantial amounts of labelled vitamin $B_{12}$ were secreted into the duodenum and then reabsorbed throughout the length of the ileum. 'Iransitorily high levels of vitamin $\mathrm{B}_{12}$ activity for Ochromonas or $L$. leichmanii have been reported in the small intestine of sheep (Hine \& Dawbarn, 1954; Kercher \& Smith, I 956).

After injection of labelled cobalamins the specific activities $(\mu \mathrm{Ci} / \mathrm{g}(\mathrm{dry}))$ of tract contents immediately above and below the small intestine were about the same, indicating that most of the vitamin $\mathrm{B}_{12}$ secreted into the duodenum was reabsorbed. 'This is in marked contrast to the poor absorption of vitamin $B_{12}$ coming from the rumen and presumably released from bacteria in the acid conditions of the abomasum (Table 1 ). The poor absorption of vitamin $\mathrm{B}_{12}$ coming from the rumen is unexplained but, in view of the high efficiency of reabsorption, it would not appear to be due to competition for intrinsic factor by other cobamides.

The distribution of labelled cobalamins in alimentary tract contents provides no evidence for absorption of vitamin $B_{12}$ below the small intestine and shows that little injected vitamin $B_{12}$ entered the rumen. The activities in bile in the two experiments were widely divergent and with injected $5^{\prime}$-deoxyadenosyl $\left[{ }^{6} \mathrm{Co}\right]$ cobalamin the activity was much lower than that in the duodenum and upper ileum. No conclusions can be reached as to the means of secretion of vitamin $B_{12}$ into the duodenum.

The distribution in tissues of the two labelled cobalamins was similar and in general resembled that in other animals, with liver and kidneys the chief sites of retention (Reizenstein, 1959; Gräsbeck, Ignatius, Järnefelt, Lindén, Mali \& Nyberg, I96r; Rosenblum, Reizenstein, Cronkite \& Meriwether, 1963). 'The relatively high amounts of labelled cyanocobalamin in kidneys may reflect the higher urinary excretion of this substance. Injected labelled $5^{\prime}$-deoxyadenosylcobalamin was strongly retained by the liver, and the distribution in liver cells was similar to that in rat liver (Newman, O'Brien, Spray \& Witts, 1962). A feature of interest is the relatively high activity found in the walls of the rumen. The epithelium of this tissue, like liver mitochondria, actively metabolizes propionate (Pennington $\&$ Sutherland, 1956; Smith et al. 1965), a reaction sequence that involves $5^{\prime}$-deoxyadenosylcobalamin (Marston \& Smith, 1961).

It is probable that faeces, rather than urine, is normally the major vehicle of excretion of vitamin $B_{12}$ released from the tissues (Dawbarn \& Hine, 1955), the balance between 
absorption and excretion being established in the small intestine. Urinary excretion of injected labelled $5^{\prime}$-deoxyadenosylcobalamin was substantially less than that of cyanocobalamin and liver retention was higher. It is possible that the relatively high urinary excretion of cyanocobalamin reflects a slower uptake by tissues of this form of vitamin $B_{12}$.

Thanks are due to Dr M. C. Dawbarn, formerly of this Division, for microbiological analysis of vitamin $B_{12}$ activity; to DrE. A. Cornish, Mr P. F. May and Mr W. B. Hall, CSIRO Division of Mathematical Statistics, for analysis of results; to Mr W. S. Osborne-White for part of the analytical work; and to Mr R. Burns for care of the animals.

\section{REFERENCES}

Barker, H. A., Smyth, R. D., Weissbach, H., Munch-Petersen, A., Toohey, J. I., Ladd, J. N., Volcani, B. E. \& Wilson, R. M. (1960). F. biol. Chem. 235, i 8 r.

Barker, H. A., Smyth, R. D., Weissbach, H., Toohey, J. I., Ladd, J. N. \& Volcani, B. E. (1960). F. biol. Chem. 235, 480 .

Comar, C. L. (1948). Nucleonics, Oct. 1948, p. 30.

Dawbarn, M. C. \& Hine, D. C. (1955). Aust. F. exp. Biol. med. Sci. 33, 335.

Dawbarn, M. C., Hine, D. C. \& Hughes, P. (1952). Nature, Lond. r7o, 793.

Dawbarn, M. C., Hine, D. C. \& Smith, J. (r957). Aust. F. exp. Biol. med. Sci. 35, 97.

Gräsbeck, R., Ignatius, R., Järnefelt, J., Lindén, H., Mali, A. \& Nyberg, W. (I96I). Clinica chim. Acta $6,56$.

Hale, W. H., Pope, A. L., Phillips, P. H. \& Bohstedt, G. (1950). F. Anim. Sci. 9, 414.

Hine, D. C. \& Dawbarn, M. C. (1954). Aust. F. exp. Biol. med. Sci. 32, 641.

Hoekstra, W. G., Pope, A. L. \& Phillips, P. H. (I952). F. Nutr. 48, 421.

Hogan, J. P. \& Weston, R. H. (1967). Aust. F. agric. Res, 18, 8०3.

Jarrett, I. G. (r948). $¥$. Coun. scient. ind. Res. Aust. 21, 3 I I.

Kercher, C. J. \& Smith, S. E. (1955). F. Anim. Sci. 14, $45^{8}$.

Kercher, C. J. \& Smith, S. E. (1956). F. Anim. Sci. 15, 550.

McDougall, E. I. (1948). Biochem. F. 43, 99.

McKenzie, H. A. \& Wallace, H. S. (1954). Aust. F. Chem. 7, 55.

Marston, H. R. (1970). Br. F. Nutr. 24, 6r 5.

Marston, H. R., Allen, S. H. \& Smith, R. M. (1961). Nature, Lond. 190, 1085.

Marston, H. R. \& Dewey, D. W. (1940). Aust. F. exp. Biol. med. Sci. 18, 343 .

Marston, H. R. \& Smith, R. M. (196I). Nature, Lond. 190, 1088.

Monroe, R. A., Sauberlich, H. E., Comar, C. L. \& Hood, S. L. (1952). Proc. Soc. exp. Biol. Med. 8o, 250.

Newman, G. E., O’Brien, J. R. P., Spray, G. H. \& Witts, L. J. (1962). In Vitamin $B_{12}$ und Instrinsic Factor: 2. Europäisches Symposion, 1961 p. 424 [H. C. Heinrich, editor]. Stuttgart: Ferdinand Enke.

Norman, A. G. \& Jenkins, S. H. (1934a). Biochem. F. 28, 2147.

Norman, A. G. \& Jenkins, S. H. (1934b). Biochem. F. 28, 2160.

Pennington, R. J. \& Sutherland, T. M. (1956). Biochem. $\mathfrak{F} .63,6$ I8.

Porter, J. W. G. (1953). Proc. Nutr. Soc. 12, 106.

Porter, J. W. G. (1957). In Vitamin $B_{12}$ und Intrinsic Factor: I. Europäisches Symposion, 1956 p. 43 [H. C. Heinrich, editor]. Stuttgart: Ferdinand Enke.

Reizenstein, P. G. (1959). Acta med. scand. 165, 467.

Rosenblum, C., Reizenstein, P. G., Cronkite, E. P. \& Meriwether, H. T. (1963). Proc. Soc. exp. Biol. Med. I12, 262.

Smith, E. L. (1965). Vitamin $B_{12}$ 3rd ed., p. 84. London: Methuen.

Smith, R. M. \& Marston, H. R. (1970). Br. F. Nutr. 24, 879.

Smith, R. M., Osborne-White, W. S. \& Russell, G. R. (1965). Biochem. F. 95, 423.

Smith, S. E. \& Loosli, J. K. (1957). F. Dairy Sci. 40, I2I 5.

Tosic, J. \& Mitchell, R. L. (1948). Nature, Lond. 162, 502.

Weston, R. H. \& Hogan, J. P. (1967). Aust. F. Agric. Res. 18, 789. 